\title{
Adsorption of arsenate on soils. Part 2: Modeling the relationship between adsorption capacity and soil physiochemical properties using 16 Chinese soils
}

\author{
Wei Jiang ${ }^{a}$, Shuzhen Zhang ${ }^{\text {a,*, }}$ Xiao-quan Shan ${ }^{\text {a }}$, Muhua Feng ${ }^{\text {a }}$, \\ Yong-Guan Zhu ${ }^{\text {a }}$, Ron G. McLaren ${ }^{b}$ \\ ${ }^{a}$ State Key Laboratory of Environmental Chemistry and Ecotoxicology, Research Center for Eco-Environmental Sciences, \\ Chinese Academy of Sciences, P.O. Box 2871, Beijing 100085, China \\ ${ }^{\mathrm{b}}$ Soil and Physical Sciences Group, Agriculture and Life Sciences Division, P.O. Box 84, Lincoln University, \\ Canterbury, New Zealand
}

Received 30 April 2004; accepted 22 March 2005

Citrate-dithionite extractable Fe has the most important positive influence on arsenate adsorption on soils.

\begin{abstract}
An attempt has been made to elucidate the effects of soil properties on arsenate adsorption by modeling the relationships between adsorption capacity and the properties of 16 Chinese soils. The model produced was validated against three Australian and three American soils. The results showed that nearly $93.8 \%$ of the variability in arsenate adsorption on the low-energy surface could be described by citrate-dithionite extractable $\mathrm{Fe}\left(\mathrm{Fe}_{\mathrm{CD}}\right)$, clay content, organic matter content $(\mathrm{OM})$ and dissolved organic carbon (DOC); nearly $87.6 \%$ of the variability in arsenate adsorption on the high-energy surface could be described by $\mathrm{Fe}_{\mathrm{CD}}$, DOC and total arsenic in soils. $\mathrm{Fe}_{\mathrm{CD}}$ exhibited the most important positive influence on arsenate adsorption. Oxalate extractable $\mathrm{Al}$ ( $\mathrm{Al} \mathrm{Ox}_{\mathrm{Ox}}$, citratedithionite extractable $\mathrm{Al}\left(\mathrm{Al}_{\mathrm{CD}}\right)$, extractable $\mathrm{P}$ and soil $\mathrm{pH}$ appeared relatively unimportant for adsorption of arsenate by soils.

(C) 2005 Elsevier Ltd. All rights reserved.
\end{abstract}

Keywords: Arsenate adsorption; Soil properties; Citrate-dithionite extractable Fe; Langmuir equation

\section{Introduction}

Adsorption of arsenic onto soil is of paramount importance because this process regulates mobility of arsenic in soil, which further influences the bioavailability and toxicity of arsenic. Previous research has shown that arsenate adsorption is related significantly to $\mathrm{Al}$ and $\mathrm{Fe}$ oxides and the clay content of soils (Wauchope, 1975; Livesey and Huang, 1981; Elkhatib et al., 1984;

\footnotetext{
* Corresponding author. Tel.: +86 10 62849683; fax: +86 10 62923563.

E-mail address: szzhang@mail.rcees.ac.cn (S. Zhang).
}

Sakata, 1987). Manning and Goldberg (1997) found that $\mathrm{Fe}$ oxide was the most important mineral influencing adsorption of arsenate. In addition, organic matter, dissolved organic carbon and phosphate in soils have all been demonstrated to suppress arsenate adsorption by displacing adsorbed arsenate from soils (Grafe et al., 2001; Liu et al., 2001; Violante and Pigna, 2002). Some studies have also examined the influence of $\mathrm{pH}$ on arsenic adsorption by soils. Pierce and Moore (1982) found that the adsorption of arsenate by amorphous iron hydroxide was substantially $\mathrm{pH}$-dependent. Goldberg (2002) investigated the $\mathrm{pH}$ dependence of arsenic adsorption on clay from $\mathrm{pH} 2$ to 10 and observed the maximum adsorption of arsenic at $\mathrm{pH}$ 2. Although 
much work has been devoted to examining the effects of soil properties on arsenate adsorption, such studies have generally used either individual soil minerals or soils with limited ranges of specific soil properties. It is generally recognized that different soil properties may have different influences on the adsorption of arsenate. Further investigation is needed, however, to identify which are the dominant soil properties that control arsenate adsorption.

We have investigated the adsorption of arsenate on 16 Chinese soils (Jiang et al., in press). Clear differences in arsenate adsorption were observed, and both Langmuir one-surface and two-surface equations were tested for fitting the arsenate adsorption data. Our objectives here were to investigate the effects of soil properties on arsenate adsorption by regression analysis between a variety of soil properties and arsenate adsorption capacities. An attempt is made to identify the most important factor affecting arsenate adsorption on soils using 16 well-characterized Chinese soils. The model produced to describe the relationship between adsorption capability and soil properties is verified by using previously published arsenate adsorption data.

\section{Materials and methods}

\subsection{Soils}

Sixteen Chinese soils were used in this study. Details of sampling, pretreatment and analysis of soil properties have been reported previously (Jiang et al., in press). The soil properties are listed in Table 1 in Jiang et al. (in press).

\subsection{The adsorption equation}

The Langmuir two-surface equation is:

$q=K_{1} M_{1} c /\left(1+K_{1} c\right)+K_{2} M_{2} c /\left(1+K_{2} c\right)$

$M_{1}$ and $K_{1}$ represent the adsorption maximum and adsorption equilibrium constant for low-energy surface and $M_{2}$ and $K_{2}$ for high-energy surface. The total adsorption maximum capacity, $M$, is written as:

$M=M_{1}+M_{2}$

\subsection{Statistical analysis}

A stepwise multiple linear regression technique of the statistical software package Statistical Product and Service Solutions (SPSS) 12.0 was used to derive the relationship between the soil properties and arsenate adsorption capacity. Origin 7.0 was used to perform simple linear regression analysis.

\section{Results}

\subsection{Regression between the adsorption maximum and the soil properties}

In Jiang et al. (in press), the Langmuir two-surface equation gave good fits to the adsorption data and was used to calculate the soil adsorption capacities used in this paper. Each surface of the Langmuir two-surface equation has its maximum adsorption capacity $\left(M_{1}\right.$ and $M_{2}$ ). The low-energy surface has a relatively low equilibrium constant $\left(K_{1}\right)$ and a high adsorption maximum $\left(M_{1}\right)$. Arsenate is loosely held on this surface. The high-energy surface has a high equilibrium constant $\left(K_{2}\right)$ and a small adsorption maximum $\left(M_{2}\right)$, and arsenate is relatively tightly held (Holford et al., 1974). Arsenate adsorption by the 16 soils varied markedly with adsorption maximum on the low-energy $\left(M_{1}\right)$ and high-energy $\left(M_{2}\right)$ surfaces ranging from 27.61 to $468.86 \mathrm{mg} \mathrm{kg}^{-1}$, and from 0 to $147.99 \mathrm{mg} \mathrm{kg}^{-1}$, respectively. The total maximum adsorption capacity $\left(M=M_{1}+M_{2}\right)$ ranged from 30.55 to $616.85 \mathrm{mg} \mathrm{kg}^{-1}$, respectively.

The adsorption maximum provides an indication of the soil's ability to retain arsenic, or conversely, the likely potential for release of adsorbed arsenic into the soil solution. Therefore, the relationship between adsorption maximum and soil properties was studied by stepwise multiple linear regression. Since the low-energy surface and high-energy surface adsorption sites might exert different effects on arsenate adsorption, we investigated the relationship between the two types of sites and soil properties separately. The total independent variables examined in the regression procedure were $\mathrm{pH}$, CEC, OM, DOC, extractable P, total arsenic, oxalateextractable $\mathrm{Fe}, \mathrm{Al}$ and $\mathrm{Mn}$ (i.e., $\mathrm{Fe}_{\mathrm{OX}}, \mathrm{Al}_{\mathrm{OX}}$, and $\mathrm{Mn}_{\mathrm{OX}}$ ), citrate-dithionite extractable $\mathrm{Fe}, \mathrm{Al}$ and $\mathrm{Mn}$ (i.e., $\mathrm{Fe}_{\mathrm{CD}}, \mathrm{Al}_{\mathrm{CD}}$, and $\mathrm{Mn}_{\mathrm{CD}}$ ), and clay content.

The stepwise regressions are shown in Table 1. The best regression model describing the relationship between the adsorption maximum on the low-energy surface $\left(M_{1}\right)$ and individual soil properties was:

$$
\begin{aligned}
M_{1}= & 0.032\left[\mathrm{Fe}_{\mathrm{CD}}\right]+6.758[\text { Clay }]-10.228[\mathrm{OM}] \\
& -0.096[\mathrm{DOC}]-116.190\left(R^{2}=0.938, \alpha<0.05\right)
\end{aligned}
$$

The best model describing the relationship between the adsorption maximum on the high-energy surface $\left(M_{2}\right)$ and individual soil properties was:

$$
\begin{aligned}
M_{2}= & 0.019\left[\mathrm{Fe}_{\mathrm{CD}}\right]-0.095[\mathrm{DOC}]-3.609[\mathrm{As}] \\
& +9.549\left(R^{2}=0.876, \alpha<0.05\right)
\end{aligned}
$$

Eqs. (3) and (4) indicate that nearly $94 \%$ of the variability in arsenate adsorption on the low-energy 
Table 1

Model summary

\begin{tabular}{|c|c|c|c|}
\hline Model & Multiple linear equation & $R^{2}$ & S.E. \\
\hline \multicolumn{4}{|c|}{ The stepwise regression for $M_{1}$} \\
\hline 1 & $M_{1}=0.050\left[\mathrm{Fe}_{\mathrm{CD}}\right]-73.757$ & 0.834 & 48.41 \\
\hline 2 & $M_{1}=0.040\left[\mathrm{Fe}_{\mathrm{CD}}\right]+3.847[$ Clay $]-135.527$ & 0.889 & 41.18 \\
\hline 3 & $M_{1}=0.034\left[\mathrm{Fe}_{\mathrm{CD}}\right]+6.317[\mathrm{Clay}]-13.419[\mathrm{OM}]-145.404$ & 0.922 & 35.87 \\
\hline 4 & $M_{1}=0.032\left[\mathrm{Fe}_{\mathrm{CD}}\right]+6.758[$ Clay $]-10.228[\mathrm{OM}]-0.096[\mathrm{DOC}]-116.190$ & 0.938 & 33.45 \\
\hline \multicolumn{4}{|c|}{ The stepwise regression for $M_{2}$} \\
\hline 1 & $M_{2}=0.018\left[\mathrm{Fe}_{\mathrm{CD}}\right]-55.141$ & 0.682 & 26.69 \\
\hline 2 & $M_{2}=0.018\left[\mathrm{Fe}_{\mathrm{CD}}\right]-0.093[\mathrm{DOC}]-13.117$ & 0.810 & 21.41 \\
\hline 3 & $M_{2}=0.019\left[\mathrm{Fe}_{\mathrm{CD}}\right]-0.095[\mathrm{DOC}]-3.609[\mathrm{As}]+9.549$ & 0.876 & 17.92 \\
\hline
\end{tabular}

S.E. $=$ standard error of the estimate.

surface could be described by $\mathrm{Fe}_{\mathrm{CD}}$, clay, $\mathrm{OM}$ and DOC, and nearly $88 \%$ of the variability in arsenate adsorption on the high-energy surface could be described by $\mathrm{Fe}_{\mathrm{CD}}$, DOC and the total arsenic concentration in soils. Incorporating other measured soil properties did not improve the model fitting. The variance inflation factor (VIF) of every independent variable was lower than 4.0 , which suggested that collinearity between independent variables was not significant (collinearity becomes an issue when values of VIF exceed 4.0).

\subsection{Application of the model to other soils}

The published arsenate adsorption data and soil properties of three Australian (Smith et al., 2002) and three American soils (Manning and Goldberg, 1997) were used to validate the model for describing the relationship between the adsorption maximum and soil properties. Because DOC values of these soils were not provided, we selected the best regression models that did not include DOC as a variable (Table 1) to predict adsorption maximum on the both surfaces. These are:

$$
\begin{aligned}
M_{1}= & 0.034\left[\mathrm{Fe}_{\mathrm{CD}}\right]+6.317[\mathrm{Clay}]-13.419[\mathrm{OM}] \\
& -145.404\left(R^{2}=0.922\right)
\end{aligned}
$$

$M_{2}=0.018\left[\mathrm{Fe}_{\mathrm{CD}}\right]-55.141\left(R^{2}=0.682\right)$.

For the low energy surface adsorption maximum $\left(M_{1}\right)$, the capacities for the Australian and American soils predicted from Eq. (5), involving $\mathrm{Fe}_{\mathrm{CD}}$, Clay \% and OM, agreed well with the capacities calculated by linear regression analysis of the adsorption isotherm data (Fig. 1). The slope (close to 1) and the coefficients of determination indicated very strong correlations. The small differences in intercepts could be caused by the different methods used to measure the soil properties in the three studies. The high-energy surface adsorption capacities in these soils were poorly predicted using only the $\mathrm{Fe}_{\mathrm{CD}}$ variable (Eq. (6)). This is perhaps not surprising since even for the Chinese soils $\mathrm{Fe}_{\mathrm{CD}}$ alone could only account for $68.2 \%$ of the variability in arsenate adsorption on the high-energy surface (Table 1). Thus $\mathrm{Fe}_{\mathrm{CD}}$ cannot be used to calculate the adsorption maximum on this surface accurately without integrating with other soil properties, especially DOC, which is the next important factor following $\mathrm{Fe}_{\mathrm{CD}}$.

\section{Discussion}

Eqs. (3) and (4) verified that arsenate adsorption on the low-energy surface could be described by $\mathrm{Fe}_{\mathrm{CD}}$, clay, $\mathrm{OM}$ and DOC; arsenate adsorption on the highenergy surface could be described by $\mathrm{Fe}_{\mathrm{CD}}$, DOC and total arsenic concentration in soils. $\mathrm{Fe}_{\mathrm{CD}}$ was the first independent variable fitted to both models by stepwise regression and could describe $83.4 \%$ of the variability in arsenate adsorption on the low-energy surface and $68.2 \%$ of the variability in arsenate adsorption on the high-energy surface (Table 1). Manning and Goldberg (1997) also observed that $\mathrm{Fe}_{\mathrm{CD}}$ was the controlling factor for arsenate adsorption on three American soils

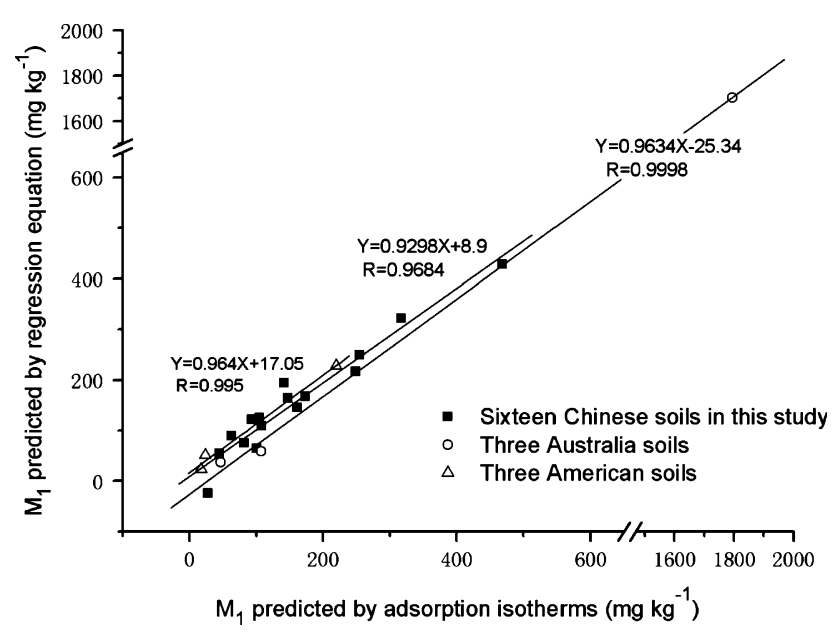

Fig. 1. The relationship between the low-energy surface adsorption maximum $\left(M_{1}\right)$ predicted from the regression model and from adsorption isotherm data for American, Australian and Chinese soils. 
as predicted using the Langmuir equation. McKeague and Day (1965) found that oxalate extraction was capable of dissolving much of the iron oxide from amorphous materials but little from crystalline oxides, whereas the dithionite extraction was capable of dissolving a large proportion of the crystalline iron oxides as well as much of the amorphous materials. In this study the content of $\mathrm{Fe}_{\mathrm{CD}}$, but not $\mathrm{Fe}_{\mathrm{OX}}$, showed positive correlations with both $M_{1}$ and $M_{2}$, indicating that not only noncrystalline iron forms, but also crystalline forms were related to the adsorption capacity of arsenate on soils.

Clay content would enhance arsenate adsorption on the low-energy surface because clay minerals can provide adsorption sites for arsenic. The adsorption behavior of arsenic on clay minerals is similar to that on the oxides although the adsorption affinity is less than that on oxides (Goldberg, 2002). On the other hand, soils containing higher percentages of clay would have larger surface areas, which is important for adsorption. However, the results of this study showed that clay content was less important than $\mathrm{Fe}_{\mathrm{CD}}$ for arsenic adsorption. By using sequential extraction to remove specific components from a lateritic podzol, Fordham and Norrish (1983) also confirmed that iron oxides were the components most reactive to arsenate and that titanium and aluminium oxides, and clay minerals were much less reactive.

The regression results showed that soil organic matter had a negative effect on arsenate adsorption. Organic matter in soils can combine with soil minerals (Kaiser and Guggenberger, 2003) and may participate in the formation of microaggregates of iron oxides and fine kaolin (Fordham and Norrish, 1983), therefore reducing adsorption sites and suppressing arsenate adsorption on soils. Dissolved organic carbon suppressed arsenic adsorption on both high-energy and low-energy surfaces. Dissolved organic carbon is a very important factor controlling the equilibrium between adsorbent and adsorbate. It is also possible that dissolved organic carbon competed with arsenic for adsorption to mineral surfaces, or formed complexes with arsenate, hence reducing arsenic adsorption (Grafe et al., 2001). Extractable $\mathrm{P}$ was not involved in the regression equations although competition between adsorption of phosphate and arsenate has been frequently demonstrated (Roy et al., 1986; Liu et al., 2001; Violante and Pigna, 2002).

A previous study (Goldberg, 2002) of arsenic adsorption by using soil minerals suggested that arsenic adsorption was $\mathrm{pH}$ dependent. However, in this study, soil $\mathrm{pH}$ did not appear as an important variable in predicting the arsenate adsorption maxima $M_{1}$ and $M_{2}$. This phenomenon was also observed by De Brouwere et al. (2004). The relationship between soil $\mathrm{pH}$ and arsenate adsorption by a variety of soils cannot be compared with the results obtained by one single soil or soil mineral with the $\mathrm{pH}$ artificially changed. In the latter case, not only the soil $\mathrm{pH}$ but also some other soil properties could be changed concomitantly (Alves and Lavorenti, 2004). It is therefore hard to conclude that effects are solely caused by the soil $\mathrm{pH}$.

\section{Conclusions}

Our results indicated that arsenate adsorption onto soils varied greatly with the soil properties. Among the soil properties, $\mathrm{Fe}_{\mathrm{CD}}$ exhibited the most important positive influence on arsenate adsorption. Clay content also had a positive effect on adsorption mainly on lowenergy surface sites. Soil organic matter content suppressed arsenate adsorption on the low-energy surface adsorption sites and DOC was negatively correlated to arsenic adsorption on both the high-energy and lowenergy surfaces. The variables $\mathrm{Al}_{\mathrm{Ox}}, \mathrm{Al}_{\mathrm{CD}}$, extractable $\mathrm{P}$ and soil $\mathrm{pH}$ appeared relatively unimportant for arsenate adsorption on soils.

\section{Acknowledgements}

This work was funded by National Basic Research Program (2003CB415004), Chinese Academy of Sciences (grant No. KZCX3-SW-431) and National Natural Science Foundation of China (No. 20377049 and No. 20237010).

\section{References}

Alves, M.E., Lavorenti, A., 2004. Sulfate adsorption and its relationships with properties of representative soils of the Sao Paulo State, Brazil. Geoderma 118, 89-99.

De Brouwere, K., Smolders, E., Merckx, R., 2004. Soil properties affecting solid-liquid distribution of As (V) in soils. European Journal of Soil Science 55, 165-173.

Elkhatib, E.A., Bennett, O.L., Wright, R.J., 1984. Arsenite sorption and desorption in soils. Soil Science Society of America Journal 48, $1025-1030$.

Fordham, A.W., Norrish, K., 1983. The nature of soil particles particularly those reacting with arsenate in a series of chemically treated samples. Australian Journal of Soil Research 21, 455-477.

Goldberg, S., 2002. Competitive adsorption of arsenate and arsenite on oxides and clay minerals. Soil Science Society of America Journal 66, 413-421.

Grafe, M., Eick, M.J., Grossl, P.R., 2001. Adsorption of arsenate(V) and arsenite (III) on goethite in the presence and absence of dissolved organic carbon. Soil Science Society of America Journal $65,1680-1687$.

Holford, I.C.R., Wedderburn, R.W.M., Mattingly, G.E.G., 1974. A Langmuir two-surface equation as a model for phosphate adsorption by soils. Journal of Soil Science 25, 242-255.

Jiang, W., Zhang, S., Shan, X., Feng, M., Zhu, Y., McLaren, R.G. Adsorption of arsenate on soils. Part 1: Laboratory batch experiments using sixteen Chinese soils with different physiochemical properties. Environmental Pollution, in press. 
Kaiser, K., Guggenberger, G., 2003. Mineral surfaces and soil organic matter. European Journal of Soil Science 54, 219-236.

Liu, F., De Cristofaro, A., Violante, A., 2001. Effect of pH, phosphate and oxalate on the adsorption/desorption of arsenate on/from goethite. Soil Science 166, 197-208.

Livesey, N.T., Huang, P.M., 1981. Adsorption of arsenate by soils and its relation to selected chemical properties and anions. Soil Science $131,88-94$

Manning, B.A., Goldberg, S., 1997. Arsenic(III) and arsenic(V) adsorption on three California soils. Soil Science 162, 886-895.

McKeague, J.A., Day, J.H., 1965. Dithionite- and oxalate-extractable $\mathrm{Fe}$ and $\mathrm{Al}$ as aids in differentiating various classes of soils. Canadian Journal of Soil Science 46, 13-23.

Pierce, M.L., Moore, C.B., 1982. Adsorption of arsenite and arsenate on amorphous iron hydroxide. Water Research 16, 1247-1253.
Roy, W.R., Hassett, J.J., Griffin, R.A., 1986. Competitive coefficient for the adsorption of arsenate, molybdate, and phosphate mixtures by soils. Soil Science Society of America Journal 50, 1176-1182.

Sakata, M., 1987. Relationship between adsorption of arsenic(III) and boron by soil and soil properties. Environmental Science and Technology 21, 1126-1130.

Smith, E., Naidu, R., Alston, A.M., 2002. Chemistry of inorganic arsenic in soils: II. Effect of phosphorus, sodium, and calcium on arsenic sorption. Journal of Environmental Quality 31, 557-563.

Violante, A., Pigna, M., 2002. Competitive sorption of arsenate and phosphate on different clay minerals and soils. Soil Science Society of America Journal 66, 1788-1796.

Wauchope, R.D., 1975. Fixation of arsenical herbicides, phosphate and arsenate in alluvial soils. Journal of Environmental Quality 4, $355-358$. 